\title{
Evidence for Selective Caching by Arctic Ground Squirrels Living in Alpine Meadows in the Yukon
}

\author{
ELIZABETH A. GILLIS, ${ }^{1}$ SHAWN F. MORRISON,${ }^{2}$ GRANT D. ZAZULA ${ }^{3}$ and DAVID S. HIK ${ }^{2}$
}

\author{
(Received 10 December 2004; accepted in revised form 6 April 2005)
}

\begin{abstract}
Male arctic ground squirrels (Spermophilus parryii) rely on food they cached the previous year for the energy they need to compete for mates each spring. We collected cheek-pouch contents of arctic ground squirrels trapped during three summers (2000-02) as an indication of what squirrels cached. Among adults, both males and females carried material in their cheek pouches, but males did so more frequently than females ( $4.4 \%$ vs. $0.6 \%$ of captures). Males carried material later in the summer than females, and also carried different material (seeds and rhizomes as opposed to nesting material). These differences probably reflect different purposes of cheek-pouch contents-females carried material for immediate use, whereas males carried food for caching. Only 24 of over 100 species of vascular plants growing at our alpine study site were carried, and presumably cached, by male arctic ground squirrels. The seeds or rhizomes of one species, Polygonum viviparum, were found in over $90 \%$ of cheek-pouch contents examined, even though that species grew at relatively low density and was no more common than another species in the same genus (Polygonum bistorta) that was never found in cheek-pouch contents. Collectively, this evidence indicates that males are highly selective in what species they cache. Many of the species carried by arctic ground squirrels in this study have also been found in Pleistocene fossil caches from central Yukon, indicating that food preferences of this species may have remained stable over time.
\end{abstract}

Key words: arctic ground squirrel, Spermophilus parryii, food caching, hoarding, Polygonum, alpine

RÉSUMÉ. Les spermophiles arctiques mâles (Spermophilus parryii) dépendent de la nourriture qu'ils ont cachée l'année précédente pour obtenir l'énergie dont ils ont besoin pour se trouver une compagne d'accouplement au printemps. On a recueilli le contenu des abajoues de spermophiles arctiques capturés pendant trois étés (de 2000 à 2002) pour obtenir un aperçu de ce qu'ils emmagasinaient. Les spermophiles adultes, tant mâles que femelles, transportaient des matériaux dans leurs abajoues, mais c'était plus souvent le cas chez les mâles que chez les femelles ( $4,4 \%$ par rapport à $0,6 \%$ des spermophiles capturés). Les mâles transportaient des matériaux plus tard pendant l'été que les femelles, sans compter que ces matériaux étaient différents (des graines et des rhizomes par opposition à des matériaux destinés à la nidification). Ces différences sont probablement le reflet de la raison d'être différente du contenu des abajoues — les femelles transportaient des matériaux dont elles allaient se servir immédiatement, tandis que les mâles transportaient des aliments qu'ils allaient mettre en réserve. Sur la centaine d'espèces de plantes vasculaires poussant au site alpin que nous avons étudié, seulement 24 d'entre elles étaient présentes. Ces plantes avaient probablement été mises en réserve par les spermophiles arctiques mâles. Les graines ou les rhizomes d'une espèce, soit le Polygonum viviparum, ont été trouvés dans plus de $90 \%$ du contenu des abajoues examiné, même si ces espèces poussaient selon des densités relativement faibles et qu'elles n'étaient pas plus courantes qu'une autre espèce du même genre (Polygonum bistorta) qui ne se retrouvait jamais dans le contenu des abajoues. Dans l'ensemble, cela indique que les mâles font preuve d'une grande sélectivité quant aux espèces qu'ils mettent en réserve. Grand nombre des espèces transportées par les spermophiles arctiques visés par cette étude ont également été retrouvées dans les caches fossiles du Pléistocène du centre du Yukon, ce qui laisse croire que les préférences alimentaires de cette espèce n'ont guère changé au fil du temps.

Mots clés: spermophile arctique, Spermophilus parryii, réserves alimentaires, Polygonum, alpin

Traduit pour la revue Arctic par Nicole Giguère.

\section{INTRODUCTION}

For animals living in seasonal environments, food abundance, quality, and access vary throughout the year. Animals have evolved a variety of ways to deal with predictable periods of food scarcity, such as migrating, hibernating, storing fat, and caching food (Vander Wall, 1990;
Marchand, 1996). Of these, only food caching and nonhibernating fat storage allow animals to remain active and engage in energetically costly activities when food is either unavailable or of low quality (Rutter, 1972; Vander Wall, 1990). Food caching is a common behaviour for many mammals living in the North, including coyotes (Canis latrans; O'Donoghue et al., 1998), red squirrels

\footnotetext{
${ }^{1}$ Department of Biology, St. Francis Xavier University, P.O. Box 5000, Antigonish, Nova Scotia B2G 2W5, Canada; eagillis@ @tfx.ca

${ }^{2}$ Department of Biological Sciences, University of Alberta, Edmonton, Alberta T6G 2E9, Canada

${ }^{3}$ Department of Biological Sciences, Simon Fraser University, 8888 University Drive, Burnaby, British Columbia V5A 1S6, Canada

(C) The Arctic Institute of North America
} 
(Tamiasciurus hudsonicus; Hurly and Robertson, 1987), pikas (Ochotona collaris; MacDonald and Jones, 1987), beavers (Castor canadensis; Marchand, 1996), voles (Microtus and Clethrionomys spp.; Vander Wall, 1990), and arctic ground squirrels (Buck and Barnes, 1999).

Arctic ground squirrels (Spermophilus parryii) avoid winter food shortages primarily by hibernating individually for up to eight months each year (McLean and Towns, 1981). Adult females are inactive from late July to late April each year, approximately 20 days longer than adult males, who are inactive from late August until mid-April (McLean and Towns, 1981; Buck and Barnes, 1999). Individuals of both sexes lose $30-48 \%$ of their fall body mass during hibernation, but males emerge above ground in the spring weighing the same as the previous fall (Buck and Barnes, 1999). Males accomplish this by caching seeds and fruits in the fall and eating these foods in the spring during a period in which they are euthermic but have not left their hibernacula (Buck and Barnes, 1999). Males need this period, which lasts approximately two weeks, to complete testicular growth and spermatogenesis (Barnes and Ritter, 1993). In contrast, females, who do not cache seeds, emerge from hibernation three to six days after becoming euthermic weighing 30\% less than they did the previous fall (Buck and Ritter, 1993; Buck and Barnes, 1999). The sex difference in caching behaviour is related to the higher cost of breeding for males (Michener, 1998; Buck and Barnes, 1999). Not only must males increase body temperature before the breeding season to facilitate sperm production, but they engage in intense male-male competition for mating opportunities when vegetation is still snow-covered and unavailable (Carl, 1971). Energy expenditure for males is so great during the three- to fourweek mating period that they can lose all the mass they regained from eating their food caches (Buck and Barnes, 1999). Thus caches are essential for reproductive success of males, but not of females (McLean and Towns, 1981; Buck and Barnes, 1999). Males with insufficient caches may emerge in poorer condition and have lower mating success (Gillis, 2003) or even forgo the breeding season (Buck and Barnes, 1999).

Despite the necessity of cached plants for reproductive success of male arctic ground squirrels, little is known about what types of plants these squirrels cache. From recent times, specific contents have been published only for partial caches from two individuals in Arctic Alaska. One partial cache contained only $P$. viviparum seeds (Mayer, 1953), and the other contained leaves of Salix, spikes of a grass (Agropyron), and seeds of a rush (Juncus; Krog, 1954). Ongoing paleontological work on fossil arctic ground squirrel nests and caches in central Yukon, however, reveals that a much wider variety of species was cached in the past. Three middens radiocarbon-dated to the late Pleistocene (ca. 24500 years ago) contained taxa representing 18 species of mosses, 6 graminoids, 16 forbs, and 1 species of dwarf shrub (Zazula et al., 2005). Comparing fossil caches with recent caches facilitates examina- tion of caching behaviour and environmental adaptation over evolutionary time scales. This study therefore aimed to document the foods arctic ground squirrels in an alpine environment currently cache (as indicated by what they carry in their cheek pouches), with particular emphasis on two species of Polygonum, a genus frequently found in male cheek-pouch contents.

\section{MATERIALS AND METHODS}

This study was conducted in a $4 \mathrm{~km}^{2}$ alpine valley in the Ruby Range near Kluane Lake, southwestern Yukon $\left(61^{\circ} 20^{\prime} \mathrm{N}, 138^{\circ} 25^{\prime} \mathrm{W}\right.$, elevation $\left.1600-1900 \mathrm{~m}\right)$. Approximately 100 species of vascular plants have been recorded at our site, with communities dominated by Salix spp., Carex consimilis, and Dryas octopetala (McIntire and Hik, 2002). Ground cover at the site was a mosaic of unvegetated boulder fields (36\%); patches of moss, lichens, and bare ground (37\%); and vascular plants (27\%). Daily surface temperatures from June to August range from below $0^{\circ} \mathrm{C}$ to $+40^{\circ} \mathrm{C}$ (McIntire and Hik, 2002).

We collected cheek-pouch contents from ground squirrels live-trapped as part of a study examining arctic ground squirrel demography and dispersal (Gillis, 2003; Gillis et al., 2005). During 28 May - 10 August 2000, 28 April-10 August 2001, and 27 April-26 July 2002, we live-trapped arctic ground squirrels in Tomahawk traps baited with peanut butter. Juveniles (young of year) started entering traps on 23-27 June each year, shortly after emerging from their natal nests (about 26 days after birth; Lacey, 1991). We ear-tagged each squirrel with a unique number the first time it was trapped, and on every subsequent recapture we recorded identity, age (juvenile or adult), and gender. We also recorded whether the squirrel was carrying material, as indicated by enlarged cheek pouches.

Trapped individuals carrying material expelled their cheek-pouch contents when we approached the trap, and we collected a sample, ensuring that all content types were included. We later identified the material using a reference collection and herbarium specimens collected from the local area. On two occasions, squirrels (one adult male and one adult female) did not expel their cheek-pouch contents during handling, so we recorded the contents as unknown. Because trapping effort varied among periods and some individuals were captured more frequently than others, results are reported as percent of captures and percent of individuals captured that had food in their cheeks.

Previous experience with trapping squirrels in our area indicated Polygonum seeds and rhizomes would be common items carried in cheek pouches. We therefore conducted quadrat surveys to quantify the abundance of these items at the site on 16 July 2002 . We ran $20 \mathrm{~m}$ transects perpendicular to the slope at 10 locations with east-facing slopes and 12 locations with west-facing slopes. We recorded the total number and number of flowering $P$. viviparum and $P$. bistorta in $0.5 \mathrm{~m} \times 0.5 \mathrm{~m}$ quadrats 


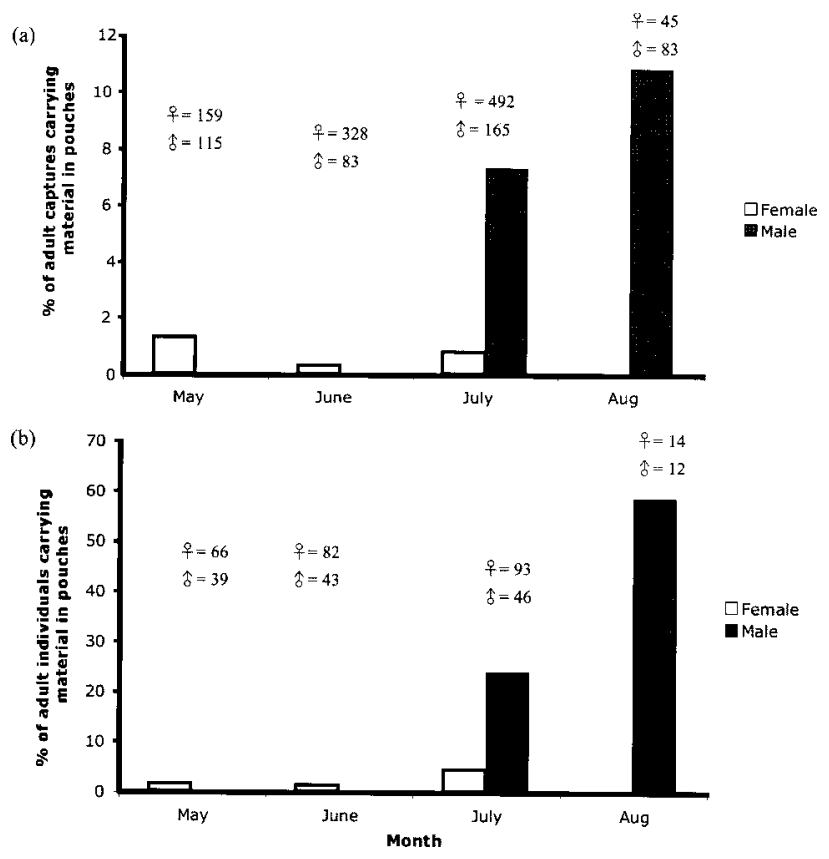

FIG. 1. Seasonal trends in the percentage of adult male and female squirrels that had foods or nesting material in their cheek pouches, based on total number of captures (a) and total number of individuals (b). Gender symbols and numbers above the monthly bars indicate (a) total number of captures in that month and (b) the number of different individuals captured in that month.

placed at $0 \mathrm{~m}, 10 \mathrm{~m}$, and $20 \mathrm{~m}$ along the transect. We then calculated mean density of $P$. bistorta and $P$. viviparum and categorized the elevation of each transect as low $(1600-1700 \mathrm{~m}, \mathrm{n}=9)$, mid $(1700-1800 \mathrm{~m}, \mathrm{n}=7)$, or high $(>1800 \mathrm{~m}, \mathrm{n}=6)$. At three elevations $(1630 \mathrm{~m}, 1750 \mathrm{~m}$, and $1830 \mathrm{~m}$ ), we removed the underground rhizome of the first 10 flowering and first 10 non-flowering plants of each species and measured its dry mass $( \pm 0.001 \mathrm{~g})$.

All statistical analyses were performed using JMP 5.1 (Sall et al., 2001) and $\alpha=0.05$ was used to determine statistical significance. Unless otherwise stated, all values are reported as mean \pm 1 S.E. Prior to parametric statistical analysis, we tested assumptions of equal variances and normality of data. Data were transformed if necessary, and non-parametric statistics were used if parametric assumptions could not be met (Zar, 1999). We removed nonsignificant interaction terms from the final statistical models.

\section{RESULTS}

No differences were detected among years, so data from all years were combined for analysis of cheek-pouch contents. Adult males were more likely to be carrying food when captured than were adult females (Pearson's $\chi^{2}=$ $405.6, p<0.001, \mathrm{df}=2$ ). From 2000 to 2002 , in $4.4 \%$ of captures of adult males $(n=471)$ and $0.6 \%$ of captures of adult females $(\mathrm{n}=1032)$, the individuals had material in their cheek pouches. Of 170 juvenile males caught 338 times, only one individual had full cheek pouches. We

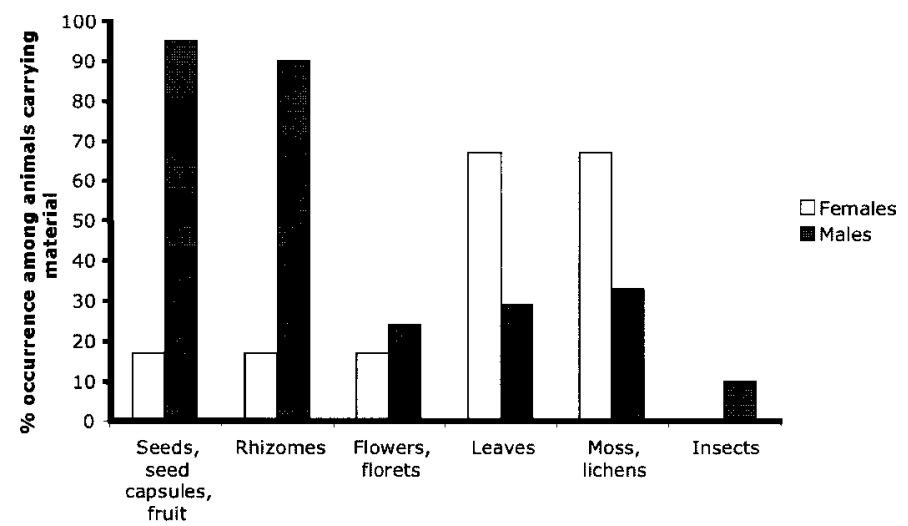

FIG. 2. Comparison of cheek-pouch contents expelled by adult female $(n=6)$ and male $(\mathrm{n}=21)$ arctic ground squirrels trapped from 2000 to 2002 at our alpine study site. Insects were excluded from the statistical analysis, and all sexual reproductive structures (seeds, seed capsules, fruit, flowers, and florets) were combined into one group.

never observed material in the cheek pouches in any of 160 juvenile females trapped 375 times.

Males and females differed in their seasonal timing of seed collection (Wilcoxon signed-rank test, $\chi^{2}=15.0$, $p=0.001$, df $=1)$. Females carried material during the breeding season and lactation period (latest July 17), whereas males carried material after the breeding season, typically during the pre-hibernation period in late July and August (earliest 14 July; Fig. 1).

Males and females also carried different material in their cheek pouches (Pearson's $\chi^{2}=11.4, p=0.01$, df $=3$ ). Nesting materials, such as moss and lichens, were the materials most commonly carried by females, but these were rarely found in the cheek-pouch contents of males (Fig. 2). Conversely, females rarely carried seeds or rhizomes in their cheek pouches, whereas males almost always did (Fig. 2).

At least 24 species of vascular plants were found in the cheek-pouch materials of males (Table 1). The most common species was Polygonum viviparum. Of the 21 male cheek-pouch contents collected, 18 contained both seeds and rhizomes of $P$. viviparum. In contrast, we found no Polygonum bistorta in any of the cheek-pouch samples. Other genera commonly found in the cheek pouches of males were Luzula, Carex, Ranunculus, Potentilla, Cerastium, Draba, Cardamine, and Eutrema. On average, for the 20 samples in which all material could be identified, 5.6 \pm 0.6 (range 1-9) different species of plants were found in each cheek-pouch contents.

Both Polygonum bistorta and $P$. viviparum species grew at the site at approximately equal densities (20.9 \pm 5.6 per $\mathrm{m}^{2}$ and $19.7 \pm 4.9$ per $\mathrm{m}^{2}$, respectively), and both species were highly aggregated in distribution. An index of dispersion (I) of 1.0 indicates a random spatial distribution (Krebs, 1999), and we found $\mathrm{I}=15.4,\left(\chi^{2}=31001\right.$, $p<0.001)$ for $P$. bistorta and $\mathrm{I}=13.5\left(\chi^{2}=878, p<0.001\right)$ for $P$. viviparum. Density of flowering Polygonum plants was low ( $P$. bistorta $1.1 \pm 0.6$ per $\mathrm{m}^{2}, P$. viviparum $2.8 \pm$ 0.7 per $\mathrm{m}^{2}$ ), and flowering $P$. bistorta was less common 
TABLE 1. Vascular plant material carried in the cheek pouches of male ground squirrels trapped at our alpine study site. Material was expelled by squirrels and samples collected 21 times from 2000 to 2002 . Frequency is the number of samples in which the plant species was found, and relative frequency is the percent of total occurrences, where total occurrence $=\sum$ frequency $=120$.

\begin{tabular}{|c|c|c|c|c|}
\hline Family & Taxon & Plant Part $^{1}$ & Frequency & Relative Frequency (\%) \\
\hline \multirow[t]{2}{*}{ Polygonaceae } & Polygonum viviparum & S & 19 & 15.8 \\
\hline & Polygonum viviparum & B & 18 & 15.0 \\
\hline Juncaceae & Luzula spp. ${ }^{2}$ & $\mathrm{C}$ & 12 & 10.0 \\
\hline \multirow{2}{*}{ Cyperaceae } & Carex spp. ${ }^{3}$ & A, P, SL & 12 & 10.0 \\
\hline & Kobresia myosuroides & A & 1 & 0.8 \\
\hline \multirow[t]{2}{*}{ Ranunculaceae } & Ranunculus sp. & A & 9 & 7.5 \\
\hline & Anemone parviflora & A & 1 & 0.8 \\
\hline \multirow{2}{*}{ Rosaceae } & Potentilla sp. & A & 7 & 5.8 \\
\hline & Dryas octopetala & $\mathrm{L}$ & 2 & 1.7 \\
\hline \multirow[t]{3}{*}{ Brassicaceae } & Cardamine sp. & S, SQ & 5 & 4.2 \\
\hline & Draba spp. $^{4}$ & $\mathrm{~S}, \mathrm{SC}$ & 6 & 5.0 \\
\hline & Eutrema edwardsii & S, SQ & 4 & 3.3 \\
\hline \multirow[t]{2}{*}{ Caryophyllaceae } & Cerastium beeringianum & $\mathrm{C}$ & 5 & 4.2 \\
\hline & Silene uralensis & $\mathrm{C}$ & 1 & 0.8 \\
\hline \multirow{4}{*}{ Poaceae } & Festuca brachyphylla & $\mathrm{F}$ & 3 & 2.5 \\
\hline & Hierochloë alpina & $\mathrm{F}$ & 1 & 0.8 \\
\hline & Poa arctica & SP & 1 & 0.8 \\
\hline & Trisetum spicatum & SP & 1 & 0.8 \\
\hline Saxifragaceae & Saxifraga sp. & $\mathrm{C}$ & 4 & 3.3 \\
\hline \multirow{2}{*}{ Salicaceae } & Salix arctica, S. polaris & $\mathrm{L}$ & 3 & 2.5 \\
\hline & Salix reticulata & $\mathrm{C}$ & 1 & 0.8 \\
\hline Gentianaceae & Gentiana prostrata & $\mathrm{C}$ & 1 & 0.8 \\
\hline Scrophulariaceae & Pedicularis sp. & $\mathrm{C}, \mathrm{F}, \mathrm{L}, \mathrm{S}$ & 2 & 1.7 \\
\hline Unidentified vegetation & & $\mathrm{L}$ & 1 & 0.8 \\
\hline
\end{tabular}

than flowering $P$. viviparum at low and mid elevations $(p<0.05)$.

Dry mass of Polygonum rhizomes varied with species, plant reproductive condition, and elevation (log transformed data ANOVA $F_{4,75}=47.54, p<0.0001$; Table 2). Mass of Polygonum rhizomes was significantly higher for flowering plants than for non-flowering plants $(\mathrm{F}=38.1$, $\mathrm{p}<0.001)$, significantly higher for $P$. bistorta than for $P$. viviparum $(\mathrm{F}=119.3, p<0.001)$, and higher at low elevation than at high elevation for $P$. bistorta but not for $P$. viviparum (interaction $\mathrm{F}=5.85, p=0.02$ ).

\section{DISCUSSION}

For arctic ground squirrels, we found clear intersexual differences in the frequency with which squirrels carried material in their cheek pouches, when they carried material, and what they carried (Figs. 1 and 2). These differences are likely the result of different motivations for carrying material-either for immediate use or for caching (Michener, 1993). Compared with males, females carried material less frequently and did so earlier in the season (Fig. 1), a result consistent with findings by McLean and Towns (1981). Females most frequently carried fresh vegetation, mosses, and lichens before and during the lactation period (Fig. 2).
These materials are similar to those that squirrels consume during the growing season and use as nesting material (Mayer, 1953; McLean, 1985); thus, females appeared to carry material for immediate use.

In contrast, male squirrels carried foods more likely to be cached, such as fruits and seeds (Fig. 2). Three lines of evidence suggest that males cached the foods they were carrying. McLean and Towns (1981) reported that males carrying seeds in late summer stayed underground only briefly before returning to the surface, precluding immediate consumption and strongly suggesting that the seeds were cached. Thus, the timing of males carrying material in their cheek pouches in our study is consistent with their results (McLean and Towns, 1981). Additionally, seeds were the main items present in the two excavated caches reported by Mayer (1953) and Krog (1954), so the material carried by males in our study is consistent with the type of material male arctic ground squirrels cache. Finally, male ground squirrels cache seeds, whereas females do not, because the energetic cost of mating is higher for males than for females (Shaw, 1926; Michener, 1993; Buck and Barnes, 1999).

Although the frequency of juvenile males trapped carrying material was low in this study, indicating a low incidence of caching by this age class, we believe this is primarily an artifact of ending trapping in mid-August, 
TABLE 2. Comparison of rhizome dry mass (g) of Polygonum bistorta and P. viviparum growing at three elevations (low $=1630 \mathrm{~m}$, mid $=1750 \mathrm{~m}$, and high $=1830 \mathrm{~m})$. We did not find $P$. viviparum along the lowest elevation transect. Values are reported as mean $\pm 1 \mathrm{~S} . \mathrm{E}$. ( $\mathrm{n}=10$ for each mean).

\begin{tabular}{|c|c|c|c|c|}
\hline \multirow[b]{2}{*}{ Elevation } & \multicolumn{2}{|c|}{ Non-flowering plants } & \multicolumn{2}{|c|}{ Flowering plants ${ }^{1}$} \\
\hline & P. bistorta ${ }^{2}$ & P. viviparum ${ }^{3}$ & P. bistorta ${ }^{2}$ & P. viviparum ${ }^{3}$ \\
\hline Low & $0.483 \pm 0.181$ & - & $1.466 \pm 0.295$ & - \\
\hline Mid & $0.520 \pm 0.118$ & $0.075 \pm 0.011$ & $1.676 \pm 0.127$ & $0.154 \pm 0.024$ \\
\hline High & $0.140 \pm 0.020$ & $0.067 \pm 0.014$ & $0.400 \pm 0.044$ & $0.097 \pm 0.017$ \\
\hline
\end{tabular}

${ }^{1}$ Flowering plants of both species weighed significantly more than non-flowering plants $(p<0.05)$.

${ }^{2}$ For both flowering and non-flowering plants, $P$. bistorta weighed significantly more than $P$. viviparum $(p<0.05)$. Within $P$. bistorta, plants were heavier at low elevation than at high elevation $(p<0.05)$.

${ }^{3}$ No difference in mass was detected between $P$. viviparum plants living at mid and high elevations.

before the time when juvenile males carry material more frequently (McLean and Towns, 1981). Our trapping was not extensive enough to determine whether all males cached, but almost all adult males were seen with full cheek pouches at least once during late summer (E. Gillis, unpubl. data). Both non-reproductive males and females (without caches), however, emerge from hibernacula weighing $30 \%$ less than they did in the fall (Buck and Barnes, 1999). Thus, we deduce that males that are not reproductive in spring did not create caches the previous fall.

We do not know the reasons females do not cache food, as doing so would provide insurance against food shortages caused by late snowmelt. Presumably, the costs associated with caching behaviour are high. Caching delays male immergence into hibernation (McLean and Towns, 1981), thereby extending the active season and the risk of predation, as well as the metabolic costs associated with euthermy. When caching, males often travel beyond their normal area of residency (Michener, 1993), which could further increase the risk of predation; however, survival of adult males in late summer at our site was 100\% (Gillis, 2003), so it is unlikely that predation is the main cost. Whether the metabolic costs of euthermy are greater for females than the potential benefits of having caches is unknown and warrants further investigation.

Previous studies indicate that arctic ground squirrels are selective when foraging for immediate consumption (McLean, 1985), possibly selecting for nutritional value, palatability, and local availability (McLean, 1985; Karels, 2000). This possibility was also suggested in our study, as seeds and rhizomes of $P$. viviparum were almost always present in the full cheek pouches of males, even though this species occurred at lower densities than other commonly selected species, such as Luzula or Carex. Further, most species carried by males were found in at least half of all samples, suggesting selective caching by male ground squirrels (Table 1). Similarly, caches of male Richardson's and Columbian ground squirrels (S. richardsonii and $S$. columbianus) are dominated by only a few species (Shaw, 1926; Michener, 1993).

Polygonum viviparum appears to be an important cache item for arctic ground squirrels when available. In this study, almost all (over 90\%; Table 1) of cheek-pouch samples contained $P$. viviparum; Mayer (1953) found only $P$. viviparum in a cache he excavated; and $P$. viviparum is abundant in Pleistocene fossil arctic ground squirrel caches (Zazula et al., 2005). P. viviparum is also commonly consumed or cached by other alpine herbivores, including root voles (Microtus oeconomus; Hoiland et al., 1993), Svalbard Norway ptarmigan chicks (Lagopus mutus hyperboreus; Unander et al., 1985), willow grouse chicks (Lagopus lagopus; Spidso, 1980), black ptarmigan (Lyrurus tetrix; Bernard-Laurent, 1983), and greater snow geese (Chen caerulescens atlantica; Gauthier, 1993).

There are several reasons why male squirrels may cache $P$. viviparum. First, $P$. viviparum roots have a very high starch content (64.5\%; Källman, 1991) and therefore could provide high levels of energy when eaten in the spring. Second, Polygonum spp. contain anti-inflammatory compounds (5-glutinen-3-one and friedelanol; Duwiejua et al., 1994, 1999) that may be particularly useful for males during the mating season, when they commonly suffer from multiple severe open wounds (Green, 1977; Gillis, 2003). Third, the highly aggregated distribution of $P$. viviparum could make it easy for squirrels to collect efficiently, despite its low density (Stephens and Krebs, 1986). Finally, the phenology of plants at our site likely influenced the species found in seed pouches, but since many species were available during our collection period, phenology probably does not explain the high incidence of $P$. viviparum found in male cheek pouches.

Selectivity is also suggested by the results for the one genus (Polygonum) for which we collected availability data. Over $90 \%$ of all cheek-pouch samples contained Polygonum viviparum, but none contained P. bistorta, even though it belongs to the same genus, grew at approximately equal densities at our site, and had greater rhizome mass. $P$. viviparum rhizomes have a high starch content, but it is unknown whether $P$. bistorta shares this characteristic. The density of plants was lower for $P$. viviparum at the lower elevations, but the density of flowering plants was higher, which may partially explain why male squirrels carried this species more frequently. The complete absence of $P$. bistorta in cheek-pouch contents, however, 
indicates that availability was not the primary reason for the difference in occurrence between the two species.

Pleistocene fossil nests and caches from central Yukon provide historical context and unique comparative data to this study (Zazula et al., 2005). Our cheek pouches and the fossil caches contain many common taxa, including Polygonum viviparum, Draba, Cerastium, Ranunculus, Potentilla, Gentiana prostrata, Carex, Festuca, Hierochloë, and Poa. Explanations for these similarities can only be tentative. Selection of foods to cache may be related to the nutritional content, ease of harvesting, and perishability of the different foods, and presumably squirrels' preferences have remained consistent over time (Stephens and Krebs, 1986; Vander Wall, 1990; HadjChikh et al., 1996).

In conclusion, our study documents plant species carried by arctic ground squirrels and identifies $P$. viviparum as an important species cached by males. This Arcticalpine species is widespread in the Northern Hemisphere (Dormann et al., 2002), and given the large geographic range of arctic ground squirrels (Nadler and Hoffmann, 1977), it is likely that $P$. viviparum is an important posthibernation food for male Arctic ground squirrels in both Arctic and alpine systems. Continued research on modern and Pleistocene caches may reveal further insights into the co-evolutionary relationship between foraging behaviour and Arctic, Subarctic, and alpine habitats.

\section{ACKNOWLEDGEMENTS}

Funding for this study was provided through an NSERC operating grant to C.J. Krebs. During this study, E.A. Gillis was supported by an NSERC PGS-B, a Canadian Northern Studies Trust Studentship, and the Arctic Institute of North America's Jennifer Robinson Memorial Scholarship; S.F. Morrison was supported by an Alberta Ingenuity studentship, a Canadian Northern Studies Trust studentship, and the Steve and Elaine Antoniuk Graduate Scholarship in Northern Research; and G.D. Zazula was supported by a graduate fellowship from Simon Fraser University, the Alberta provincial government's Sir James Lougheed Award of Distinction, and an NSERC operating grant to R.W. Mathewes. All research was conducted in accordance with the University of British Columbia's Animal Care Protocol A99-0281. We sincerely thank T.J. Karels and two anonymous reviewers for comments on the manuscript and the members of the Kluane First Nation for permission to conduct this research on their land.

\section{REFERENCES}

BARNES, B.M., and RITTER, D. 1993. Patterns of temperature change in hibernating arctic ground squirrels. In: Carey, C., Floarnt, G.L., Wunder, B.A., and Horwitz, B., eds. Life in the cold: Ecological, physiological, and molecular mechanisms. Boulder, Colorado: Westview Press. 119-130.
BERNARD-LAURENT, A. 1983. The diet of the black grouse Lyrurus tetrix and the rock ptarmigan Lagopus mutus in the Vallon De La Cerveyrette Hautes-Alpes France. Terre et la Vie 37:241-258.

BUCK, C.L., and BARNES, B.M. 1999. Annual cycle of body composition and hibernation in free-living arctic ground squirrels. Journal of Mammalogy 80:430-442.

CARL, E.A. 1971. Population control in arctic ground squirrels. Ecology 52:395-413.

DORMANN, C.F., ALBON, S.D., and WOODIN, S.J. 2002. No evidence for adaptation of two Polygonum viviparum morphotypes of different bulbil characteristics to length of growing season: Abundance, biomass and germination. Polar Biology 25:884-890.

DUWIEJUA, M., ZEITLIN, I.J., WATERMAN, P.G., and GRAY, A.I. 1994. Anti-inflammatory activity of Polygonum bistorta, Guaiacum officinale, and Hamamelis virginiana in rats. Journal of Pharmacy \& Pharmacology 46:286-290.

DUWIEJUA, M., ZEITLIN, I.J., GRAY, A.I., and WATERMAN, P.G. 1999. The anti-inflammatory compounds of Polygonum bistorta: Isolation and characterisation. Planta Medica 65: $371-374$

GAUTHIER, G. 1993. Feeding ecology of nesting greater snow geese. Journal of Wildlife Management 57:216-223.

GILLIS, E.A. 2003. Breeding dispersal, mating tactics, and population dynamics of arctic ground squirrels. Ph.D. thesis, University of British Columbia, Vancouver.

GILLIS, E.A., HIK, D.S., BOONSTRA, R., KARELS, T.J., and KREBS, C.J. 2005. Being high is better: Effects of elevation and habitat on arctic ground squirrel demography. Oikos 108: $231-240$.

GREEN, J.E. 1977. Population regulation and annual cycles of activity and dispersal in the arctic ground squirrel. M.Sc. thesis, University of British Columbia, Vancouver.

HADJ-CHIKH, L.Z., STEELE, M.A., and SMALLWOOD, P.D. 1996. Caching decisions by grey squirrels: A test of the handling time and perishability hypotheses. Animal Behaviour 52: 941-948.

HOILAND, K., OSTBYE, E., OSTBYE, K., and OLSEN, K.M. 1993. A winter reserve of the root vole, Microtus oeconomus (Pall.), in Hardangervidda, S Norway. Blyttia 51:17-21.

HURLY, T.A., and ROBERTSON, R.J. 1987. Scatter-hoarding by territorial red squirrels: A test of the optimal density model. Canadian Journal of Zoology 65:1247-1252.

KÄLLMAN, S. 1991. Nutritive value of Swedish wild plants. Svensk Botanisk Tidskrift 85:397-411.

KARELS, T.J. 2000. Reproduction, hibernation, and population regulation of arctic ground squirrels (Spermophilus parryii plesius). Ph.D. thesis, University of Toronto, Toronto, Ontario.

KREBS, C.J. 1999. Ecological methodology. 2nd ed. Menlo Park: Benjamin/Cummings.

KROG, J. 1954. Storing of food items in the winter nest of the Alaskan ground squirrel, Citellus undulatus. Journal of Mammalogy 35:586.

LACEY, E.A. 1991. Reproductive and dispersal strategies of male arctic ground squirrels (Spermophilus parryii plesius). Ph.D. thesis, The University of Michigan, Ann Arbor. 
MACDONALD, S.O., and JONES, C. 1987. Ochotona collaris. Mammalian Species 281:1-4.

MARCHAND, P.J. 1996. Life in the cold: An introduction to winter ecology. 3rd ed. Hanover, New Hampshire: University Press of New England.

MAYER, W.V. 1953. A preliminary study of the Barrow ground squirrel, Citellus parryi barrowensis. Journal of Mammalogy 34:334-345.

McINTIRE, E.J.B., and HIK, D.S. 2002. Grazing history versus current grazing: Leaf demography and compensatory growth of three alpine plants in response to a native herbivore (Ochotona collaris). Journal of Ecology 90:348-359.

McLEAN, I.G. 1985. Seasonal patterns and sexual differences in the feeding ecology of arctic ground squirrels (Spermophilus parryii plesius). Canadian Journal of Zoology 63:1298-1301.

McLEAN, I.G., and TOWNS, A.J. 1981. Differences in weight changes and the annual cycle of male and female arctic ground squirrels. Arctic 34(3):249-254.

MICHENER, G.R. 1993. Sexual differences in hibernaculum contents of Richardson's ground squirrels. In: Carey, C., Floarnt, G.L., Wunder, B.A., and Horwitz, B., eds. Life in the cold: Ecological, physiological, and molecular mechanisms. Boulder, Colorado: Westview Press. 109-118.

___ 1998. Sexual differences in reproductive effort of Richardson's ground squirrels. Journal of Mammalogy 79: $1-19$.

NADLER, C.F., and HOFFMANN, R.S. 1977. Patterns of evolution and migration in the arctic ground squirrel, Spermophilus parryii (Richardson). Canadian Journal of Zoology 55:748-758.
O'DONOGHUE, M., BOUTIN, S., KREBS, C.J., ZULETA, G., MURRAY, D.L., and HOFER, E.J. 1998. Functional response of coyotes and lynx to the snowshoe hare cycle. Ecology 79:1193-1208.

RUTTER, R.J. 1972. The gray jay: A bird for all seasons. Nature Canada 1:28-32.

SALL, J., LEHMAN, A., and CREIGHTON, L. 2001. JMP start statistics: A guide to statistics and data analysis using JMP and JMP IN software. 2nd ed. Pacific Grove, California: Duxbury.

SHAW, W.T. 1926. The food storing habit of the Columbian ground squirrel. American Naturalist 60:367-373.

SPIDSO, T.K. 1980. Food selection by willow grouse Lagopus lagopus chicks in northern Norway. Ornis Scandinavica 11: 99- 105 .

STEPHENS, D.W., and KREBS, J.R. 1986. Foraging theory. Princeton, New Jersey: Princeton University Press.

UNANDER, S., MORTENSEN, A., and ELVEBAKK, A. 1985. Seasonal changes in crop content of the Svalbard Norway ptarmigan Lagopus mutus hyperboreus. Polar Research 3: 239-246.

VANDER WALL, S.B. 1990. Food hoarding in animals. Chicago, Illinois: The University of Chicago Press.

ZAR, J.H. 1999. Biostatistical analysis. 4th ed. Upper Saddle River, New Jersey: Prentice Hall.

ZAZULA, G.D., FROESE, D.G., WESTGATE, J.A., LAFARGE, C., and MATHEWES, R.W. 2005. Paleoecology of Beringian "packrat" middens from central Yukon Territory. Quaternary Research 63:189-198. 